\title{
DAMPAK PEMBERITAAN PENYALAHGUNAAN FORMALIN DI SEKTOR KELAUTAN DAN PERIKANAN
}

\author{
Oleh: \\ Yayan Hikmayani, Siti Hajar Suryawati, \\ Agus Heri Purnomo, dan Zahri Nasution*
}

\begin{abstract}
ABSTRAK
Riset dampak pemberitaan penyalahgunaan formalin di sektor kelautan dan perikanan telah dilakukan pada tahun 2006. Riset ini bertujuan untuk melihat sejauhmana dampak yang ditimbulkan akibat pemberitaan tentang penyalahgunaan formalin di sektor kelautan dan perikanan pada produsen dan konsumen. Pendekatan studi digunakan melalui analisis kebijakan. Data primer dan sekunder dirumuskan sesuai keperluan analisis kebijakan ini yaitu penelusuran terhadap dampak pemberitaan formalin terhadap produsen dan konsumen di sektor kelautan dan perikanan. Kemudian data hasil verifikasi dan survey lapang yang berasal dari kuesioner dan catatan lapangan (field notes) diolah secara deskriptif untuk mendapatkan interpretasi logis. Lokasi studi ditetapkan secara sengaja (purposive) dengan kriteria tersebut merupakan sentra penanganan dan pengolahan produk perikanan dan diberitakan banyak menggunakan bahan kimia formalin yaitu Jawa Barat (Karawang), Jawa Tengah (Semarang), DKI Jakarta dan Bandar Lampung. Hasil studi menunjukkan bahwa bagi produsen yang meliputi nelayan, pengolah dan pembudidaya ikan dampak negatif dari pemberitaan formalin adalah menurunnya permintaan ikan hasil tangkapan dan olahan sehingga pendapatan nelayan dan pengolah menjadi berkurang, sedangkan bagi konsumen dampak negatifnya konsumen jadi takut mengkonsumsi ikan laut dan hasil olahan sehingga lebih memilih mengkonsumsi tempe/tahu dan telur. Dampak positifnya bagi produsen baik nelayan dan pengolah yaitu sebagian dari mereka jadi mengetahui bahwa formalin tersebut membahayakan dan berusaha tidak menggunakan lagi. Dampak positif bagi konsumen bertambah pengetahuan tentang bahaya formalin sehingga mereka akan lebih hati-hati dalam mengkonsumsi ikan dan untuk sementara konsumsi ikan mereka dialihkan ke ikan hasil budidaya yang banyak dijual dalam kondisi hidup.
\end{abstract}

Kata Kunci : Dampak, Pemberitaan, Formalin, Kelautan dan Perikanan

\section{Abstract : The Impact of Announcement on The Mis-used of Formalin in Marine and Fisheries Sector. By: Yayan Hikmayani, Siti Hajar Suryawati, Agus Heri Purnomo, and Zahri Nasution}

Research on impact of mis-used of formalin in marine and fisheries sector have been done in 2006. The aim of the research was to show the impact of announcement on the mis-used of formalin to producers and consumers. Policy analysis approach was used as the method of study. Primary and secondary data were formulated accordingly to meet the requirement of the policy analysis, that is impact of media release on both side of producers and consumers. Verified data and field survey processed descriptively to build logical interpretation. The locations of study were specified in purpose to represent the center of handling and processing of fisheries product indicated with formalyn abuse. These location were West Java (Karawang), Central Java (Semarang), DKI Jakarta and Bandar Lampung. The results of study showed that the negative impacts of the news on formalin abuse to the producers were decreasing on demand of catch and processed fish products, which in turn reduce the income of the fisherman and fish processors. On the other side, the consumer shift their preference to other products such as tempe, tofu and eggs. The positive impacts to the fisherman and fish processors were the knowledge of the danger of formalin abuse on their products and they avoid to use the chemical. The positive impact on fish consumers were the awareness on formalin use on health arose and temporary their fish consumption shifted to the aqucultured fish which sold in living form.

\section{Keywords : Impact, Announcement, Formalyn, Marine and Fisheries}

\footnotetext{
* Peneliti Pada Balai Besar Riset Sosial Ekonomi Kelautan dan Perikanan, BRKP-DKP.

JI. KS TUBUN Petamburan VI Slipi Jakarta 10260. Telp. (021) 53650159
} 


\section{PENDAHULUAN}

Isu penggunaan bahan kimia terlarang terutama formalin dalam penanganan dan pengolahan hasil perikanan marak diberitakan oleh media massa dan menyita perhatian publik. Isu yang terus berkembang di tengah masyarakat, telah menimbulkan keresahan, sehingga dikhawatirkan dapat berpengaruh terhadap stabilitas politik, ekonomi dan keamanan. Penjualan formalin secara bebas telah menyebabkan meluasnya pemakaian bahan tersebut secara luas, sehingga pemberitaan tersebut di atas membawa dampak yang menyebar ke berbagai produk yang diperdagangkan. Dampak terbesar terjadi terutama pada pengusaha-pengusaha kecil, diantaranya pengusaha ikan asin, tahu dan mie basah yang produknya diduga mengandung formalin. Tidak hanya dalam hal jenis produknya, ternyata penggunaan formalin juga meluas dalam konteks cakupan geografisnya; hampir merata di seluruh wilayah Indonesia.

Penggunaan formalin dalam produk perikanan ditemukan baik pada ikan segar ataupun ikan olahan. Penggunaan formalin pada ikan segar dipicu oleh kenaikan biaya produksi yang ditanggung oleh nelayan akibat makin jauhnya lokasi penangkapan dan makin tingginya harga solar dan harga es. Dengan penggunaan formalin, selain dapat mengurangi beban muatan, karena nelayan tidak perlu repot membawa dalam jumlah banyak, biaya produksi diperkirakan dapat ditekan hingga $\pm 20 \%$ (BBRSE, 2005).

Pemberitaan mengenai penggunaan formalin dalam produk perikanan ini, baik yang disampaikan melalui media televisi, radio ataupun media cetak memunculkan reaksi pro ataupun kontra, terkait dengan potensi dampak positif dan negatif yang timbul di masyarakat baik konsumen maupun produsen. Dampak positifnya, pemberitaan ini diyakini dapat meningkatkan pengetahuan masyarakat tentang bahaya mengkonsumsi produk yang mengandung formalin. Sementara itu, dampak negatif dari pemberitaan ini diantaranya adalah penurunan pendapatan pengusaha kecil termasuk di sektor perikanan dan penurunan konsumsi protein hewani dari produk perikanan sebagai akibat menurunnya minat mengkonsumsi ikan..

Mencuatnya kasus ini sangat mengganggu program peningkatan konsumsi ikan masyarakat yang sebelumnya sudah menunjukkan adanya tanda-tanda keberhasilan. Dilain pihak, berbagai perubahan positif yang terkait dengan isu penyalahgunaan formalin jelas perlu didukung, sedangkan dampak negatifnya harus diminimalisir. Sehubungan dengan hal tersebut berbagai solusi potensial untuk permasalahan tersebut menjadi sangat relevan. Diharapkan melalui tulisan ini dapat menampung gagasan-gagasan terbaik dari semua pihak terkait sehingga semua potensi dampak posistif dapat direalisasikan ke dalam program-program yang efektif. Dilain pihak potensi dampak negatif dapat dikurangi atau dihilangkan sama sekali.

Tulisan ini bertujuan mengemukakan persepsi masyarakat produsen dan konsumen terhadap pemberitaan penggunaan formalin yang di muat oleh media massa. Kemudian, mengemukakan pula perubahan perilaku dan pola konsumsi serta produksi masyarakat produsen sebagai akibat pemberitaan penyalahgunaan penggunaan formalin yang dilansir oleh media massa. Pada bagian akhir tulisan dikemukakan alternatif opsi kebijakan yang diperlukan untuk mendukung keberlangsungan perubahan perilaku yang bersifat positif dan berkurang atau hilangnya perubahan perilaku yang bersifat negatif tersebut.

\section{METODE}

\section{Pendekatan dan Lingkup Penelitian}

Studi dilakukan menggunakan pendekatan analisis kebijakan. Analisis kebijakan adalah suatu aktivitas intelektual yang merupakan suatu bentuk analisis yang menghasilkan dan menyajikan informasi sedemikian rupa sehingga dapat memberi landasan dari para pembuat kebijakan dalam membuat keputusan (Dunn, 2000). Dengan kata lain, analisis kebijakan adalah proses atau kegiatan mensintesa informasi, termasuk hasil-hasil penelitian, untuk menghasilkan rekomendasi opsi desain kebijakan publik (Simatupang, 2003). 
Sebagai langkah awal analisis, identifikasi isu yaitu proses yang dilakukan untuk menemukan masalah-masalah yang relevan untuk diatasi dengan tindakan kebijakan. Kebutuhan akan identifikasi isu kebijakan dapat muncul dari perubahan klien atau kebutuhan akan kebijakan baru, munculnya masalah baru dan adanya alternatif pemecahan masalah. Dalam studi ini diidentifikasi isu dan permasalahan serta kebijakan yang ada dilakukan dari berbagai pemberitaan tentang isu formlain yang ada di media massa, wawancara dengan pelaku usaha dan konsumen dan verifikasi lapang.

\section{Lokasi Penelitian}

Lokasi studi ditetapkan secara sengaja (purposive). Penetapan lokasi didasarkan kepada kriteria bahwa lokasi tersebut merupakan sentra penanganan dan pengolahan produk perikanan dan diberitakan banyak menggunakan bahan kimia formalin. Hasil pengamatan dan pengujian dilakukan oleh Badan POM menunjukkan bahwa hampir semua wilayah propinsi di Indonesia terdapat penyalahgunaan formalin. Namun demikian, berdasarkan contoh yang diperiksa oleh Badan POM diketahui bahwa daerah yang memiliki persentase terbesar kandungan formalin dalam produk perikanan dan pangan adalah Semarang (Jawa Tengah), DKI Jakarta, Bandar Lampung (Anonimous, 2006). Namun demikian, verifikasi dan pengumpulan data lapangan dilakukan pada beberapa wilayah yaitu Jawa Barat (Karawang dan Bandung), Lampung dan Semarang dengan tujuan untuk memahami sejauhmana dampak pemberitaan penggunaan formalin di sektor kelautan dan perikanan.

\section{Metode Pengumpulan dan Analisis Data}

Data yang dikumpulkan terdiri dari data primer dan sekunder. Data primer dan sekunder berupa semua data dan informasi yang berhubungan dengan hasil pengamatan, observasi, verifikasi dan atau studi pustaka yang berhubungan dengan pemberitaan penggunaan bahan kimia formalin pada wilayah yang menjadi cakupan penelitian. Data pokok yang terkait dengan penggunaan formalin pada sektor perikanan yang dimaksudkan adalah kasus penggunaan fornalin pada ikan, dampak yang ditimbulkan akibat pemberitaan formlain, kebijakan tentang pengawasan, monitoring, pengendalian penggunaan formalin. Selain itu, kebijakan yang terkait dengan produk pangan perikanan yang dikonsumsi, termasuk pendidikan dan penyuluhan terhadap konsumen mengenai produk pangan terkait dengan tugas dan fungsi institusi pembina.

Metode pengumpulan data dan fakta dilakukan menggunakan metoda survey (Singarimbun dan Effendi, 1989). Data sekunder dan primer dikumpulkan dari sumber-sumber tercatat maupun wawancara dengan responden, baik dari kalangan pejabat pemerintah yang terkait, pelaku usaha (penangkapan ikan/nelayan, pengolah produk pangan perikanan) dan konsumen/ masyarakat yang menjadi target pemasaran dari para pelaku usaha tersebut. Selain itu, dilakukan studi pustaka (literature) baik buku serta terbitan media massa untuk mengumpulkan fakta-fakta yang berhubungan dengan analisis kebijakan ini.

Data sekunder dan primer serta hasil studi pustaka dirumuskan sesuai keperluan analisis kebijakan ini yaitu penelusuran terhadap dampak pemberitaan formalin terhadap produsen dan konsumen di sektor kelautan dan perikanan. Kemudian data hasil verifikasi dan survey lapang yang berasal dari kuesioner dan catatan lapangan (field notes) diolah secara deskriptif untuk mendapatkan interpretasi logis (Nazir, 1988), yang kemudian dilanjutkan dengan Content Analysis.

\section{HASIL DAN PEMBAHASAN}

\section{Pemberitaan Tentang Penyalahgunaan Formalin Pada Produk Perikanan}

Berbagai kasus penyalahgunaan formalin pada berbagai produk perikanan dan kelautan diketahui dari hasil Inspeksi mendadak berbagai Instansi terkait disajikan melalui berbagai media massa. Sebagai contoh, berdasarkan hasil survey yang dilakukan oleh Badan POM terhadap produk makanan yang ada di Jakarta terlihat bahwa kandungan formalin pada produk perikanan berkisaran 5,86 - 40,18 ppm (Anonimous, 
Tabel 1. Hasil Temuan Penggunaan Formalin Pada Produk Perikanan di Beberapa Wilayah Yang di Tulis Di Media Massa.

Table 1. Investigation Results at The Use of Formaline in Fisheries Product in Several Areas Reported on Mass Media

\begin{tabular}{|c|c|c|c|c|}
\hline $\begin{array}{l}\text { Media massal } \\
\text { Mass Media }\end{array}$ & $\begin{array}{l}\text { Instansi/ } \\
\text { Agencies }\end{array}$ & $\begin{array}{l}\text { Lokasi/ } \\
\text { Location }\end{array}$ & $\begin{array}{l}\text { Jenis Ikan/ } \\
\text { Type of Fish }\end{array}$ & $\begin{array}{c}\text { Hasil Temuan/ } \\
\text { Investigation Results }\end{array}$ \\
\hline $\begin{array}{l}\text { Kompas, } 13 \\
\text { Januari } \\
\text { 2006/Kompas } \\
\text { January } 13^{\text {th }} \\
2006\end{array}$ & $\begin{array}{l}\text { Badan POM/Food } \\
\text { and Drug } \\
\text { Adminstration } \\
\text { Agency }\end{array}$ & $\begin{array}{l}\text { Bandar } \\
\text { Lampung }\end{array}$ & $\begin{array}{l}\text { Ikan segar, cumi, } \\
\text { kerang rebus, ikan } \\
\text { asin, cumi asin } \\
\text { dan rebon/ } \\
\text { Fresh Fish, Squid, } \\
\text { Boiled Mussels, } \\
\text { Salted Fish, } \\
\text { Salted Squid }\end{array}$ & $\begin{array}{l}\text { Dari 93`sample } \\
\text { ternyata } 34 \text { sampel } \\
\text { mengandung formalin } \\
(36,55 \%) / 34 \text { of } 94 \\
\text { samples contain } \\
\text { formalin }(36,55 \%)\end{array}$ \\
\hline $\begin{array}{l}\text { Kompas, } 30 \\
\text { Desember } \\
\text { 2006/ Kompas } \\
\text { December 30, } \\
2006\end{array}$ & & Surabaya & $\begin{array}{l}\text { Pangan olahan/ } \\
\text { Processed Food }\end{array}$ & $\begin{array}{l}\text { Dari } 91 \text { sampel } 21 \% \\
\text { terdapat pada ikan } \\
\text { segar dan } 14 \% \text { pada } \\
\text { ikan asin } / 21 \% \text { fish and } \\
14 \% \text { salted fish of } 91 \\
\text { samples }\end{array}$ \\
\hline $\begin{array}{l}\text { - Jawa Pos ,3 } \\
\text { Januari } \\
\text { 2006/Jawa Pos, } \\
\text { January 3, } 2006 \\
\\
\text { - Kompas, } 3 \\
\text { Januari 2006/ } \\
\text { Kompas, } \\
\text { January 3, } 2006\end{array}$ & $\begin{array}{l}\text { Dinas Perikanan } \\
\text { dan Kelautan/ } \\
\text { Marine and } \\
\text { Fisheries } \\
\text { Provincial Service }\end{array}$ & Jawa Tengah & $\begin{array}{l}\text { Ikan segar dan } \\
\text { olahan/ } \\
\text { Fresh and } \\
\text { Processed Fish }\end{array}$ & $\begin{array}{l}20-25 \% \text { produk } \\
\text { Perikanan yang } \\
\text { beredar di pasar } \\
\text { mengandung } \\
\text { formalin } / 20-25 \% \text { of fish } \\
\text { distributed in market } \\
\text { contain fomalin }\end{array}$ \\
\hline $\begin{array}{l}\text { Kompas, } 20 \\
\text { Januari 2006/ } \\
\text { Kompas, } \\
\text { January 20, } \\
2006\end{array}$ & $\begin{array}{l}\text { Dinas Kesehatan, } \\
\text { Kota Semarang/ } \\
\text { Health Service of } \\
\text { Semarang District }\end{array}$ & $\begin{array}{l}\text { Pasar } \\
\text { Rejomulyo, } \\
\text { Semarang }\end{array}$ & $\begin{array}{l}\text { Ikan kuniran dari } \\
\text { Pati, Ikan Teri dan } \\
\text { Silas (ikan olahan) } \\
\text { dari Demak/ } \\
\text { Yellow Tail Fish } \\
\text { from Pati, } \\
\text { Anchovies, } \\
\text { Processed Fish } \\
\text { from Demak }\end{array}$ & $\begin{array}{l}3 \text { dari } 5 \text { sampel yang } \\
\text { diuji mengandung } \\
\text { formalin, kadar } \\
\text { formalin } 10-20 \mathrm{ppm} / 3 \\
\text { of } 5 \text { tested samples } \\
\text { contain formalin in } \\
\text { concentration of } 10-20 \\
\text { ppm }\end{array}$ \\
\hline $\begin{array}{l}\text { Kompas, } 12 \\
\text { Januari 2006/ } \\
\text { Kompas, } \\
\text { January 20, } \\
2006\end{array}$ & $\begin{array}{l}\text { BPOM/ Food and } \\
\text { Drug } \\
\text { Adminstration } \\
\text { Agency }\end{array}$ & $\begin{array}{l}\text { Solo dan } \\
\text { Semarang }\end{array}$ & $\begin{array}{l}\text { Ikan asin/ } \\
\text { Salted Fish }\end{array}$ & $\begin{array}{l}57,4 \% \text { berformalin/ } \\
57,4 \% \text { of samples } \\
\text { contain formalin }\end{array}$ \\
\hline \multirow[t]{2}{*}{$\begin{array}{l}\text { Kompas } 10 \\
\text { Pebruari 2006/ } \\
\text { Kompas, } \\
\text { Pebruary 10, } \\
2006\end{array}$} & $\begin{array}{l}\text { Dinas Perikanan } \\
\text { dan Kelautan DKI } \\
\text { Jakarta/ Marine } \\
\text { and Fisheries } \\
\text { Provincial Service }\end{array}$ & $\begin{array}{l}\text { TPI Muara } \\
\text { Angke }\end{array}$ & $\begin{array}{l}\text { Ikan Laut hasil } \\
\text { tangkapan/ } \\
\text { Catched Sea Fish }\end{array}$ & $\begin{array}{l}\text { Dari } 4 \text { kapal } 1 \text { kapal } \\
\text { positif mengndung } \\
\text { formalin } 0,1 \mathrm{ppm} \text { (ikan } \\
\text { komo, kembung, } \\
\text { manyung)/ } 1 \text { of } 4 \text { ship } \\
\text { use } 0,1 \mathrm{ppm} \text { formalin } \\
\text { (rasteriger sp, }\end{array}$ \\
\hline & & TPI Cilincing, & $\begin{array}{l}\text { Ikan hasil } \\
\text { tangkapan dan } \\
\text { olahan/ } \\
\text { Catched and } \\
\text { Processed Fish }\end{array}$ & $\begin{array}{l}\text { ikan asin, ikan } \\
\text { kembung, teri basah, } \\
\text { tongkol dan } \\
\text { cumi/salted fish, } \\
\text { rasteriger sp, }\end{array}$ \\
\hline
\end{tabular}


2006). Hal ini berbahaya bagi kesehatan, karena masuknya formalin ke tubuh manusia hanya kurang lebih 30\% yang disekresi, sedangkan sisanya disimpan dalam tubuh dan menyebabkan mutasi sel. Pemberitaan lainnya di beberapa wilayah digambarkan pada Tabel 1.

Berdasarkan Tabel 1 tersebut dapat dilihat bahwa penggunaan formalin telah marak digunakan dalam produk perikanan baik dalam kondisi segar maupun ikan olahan. Hasil wawancara terhadap nelayan menunjukkan bahwa penggunaan formalin dilakukan oleh kapal-kapal besar yang waktu melautnya lama 3- 6 bulan. Hal ini dilakukan karena harga es yang mahal dan keperluannya yang cukup banyak sampai waktu yang diperlukan, sedangkan penggunaan formalin sangat minim dan tidak memerlukan ruang yang banyak untuk menyimpannya. Kemudian, penggunaan formalin untuk mengawetkan ikan dapat menurunkan biaya operasional. Sebagai ilustrasi : untuk sekali melaut selama 14 hari bilamana menggunakan memerlukan 700 es balok @ Rp 7.500,-=Rp 5,25 juta.

Di lain pihak, jika menggunakan formalin cukup 2 liter saja @ Rp 7.000,-= Rp 14.000,-. 1 (satu) liter formalin yang sudah dicampur air ini cukup untuk mengawetkan 10 ton ikan hasil tangkapan. Penggunaan formalin oleh pengolah dilakukan agar produk olahannya bertahan lama dan tidak membusuk dan berharga murah. Sementara itu, mereka tidak mengetahui bahaya yang ditimbulkan oleh penggunaan formalin.

Penggunaan formalin dalam produk pangan sangat membahayakan kesehatan, karena dapat menyebabkan efek jangka pendek dan panjang tergantung dari besarnya paparan dalam tubuh. Efek yang dapat terjadi antara lain iritasi pada saluran pernapasan, muntah-muntah, kepala pusing, rasa terbakar pada tenggorokan, penurunan suhu badan dan rasa gatal di dada. Selain itu dapat juga menyebabkan terjadinya kerusakan hati, jantung, otak, limpa, pankreas, sistem susunan syaraf pusat dan ginjal. Disamping itu penggunaan formalin dapat memicu sel pada jaringan tubuh manusia dan binatang, dan mutasi sel tersebut yang akhirnya menyebabkan penyakit kanker. Hal ini didasarkan pada kenyataan bahwa 3\% formalin yang disekresi oleh ginjal dan disekresi melalui saluran pernapasan hanya 10-20\% (Anonimous, 2006).

Sosialisasi yang kurang tentang dampak penyalahgunaan formalin menyebabkan pengguna formalin tetap menggunakan meskipun berita tentang penyalahgunaannya ramai diberitakan media massa. Padahal peraturan secara legal sudah melarang pelaku usaha yang memproduksi dan mengedarkan produk pangan untuk menggunakan formalin dalam produknya. Dalam hal ini, Balai Besar POM di Jakarta telah berupaya untuk menghentikan kegiatan tersebut, menarik dan memusnahkan produk pangan yang mengandung formalin dari peredaran. Hal ini terkait dengan pelanggaran terhadap Undang-Undang No. 7 tahun 1996 tentang Pangan yang dapat dikenai pidana penjara paling lama 5 (lima) tahun dan atau denda paling banyak Rp. 600.000.000,- (enam ratus juta rupiah), dan melanggar UU No. 8 Tahun 1999 tentang Perlindungan Konsumen yang dapat dikenai pidana penjara paling lama 5 (lima) tahun atau pidana denda paling banyak Rp. 2.000.000.000,- (dua milyar rupiah).

\section{Dampak Pemberitaan Formalin}

Pemberitaan yang terkait dengan penyalahgunaan formalin pada produk perikanan (segar dan olahan) telah memberikan dampak ekonomi dan sosial bagi usaha dan pelaku usaha di bidang perikanan. Dampak tersebut, antara lain penurunan omzet penjualan produk yang dihasilkan, sehingga menyebabkan menurunnya pendapatan mereka. Merebaknya kasus formalin pada makanan ini juga berpotensi mengakibatkan hilangnya lapangan kerja di sektor industri perikanan, terutama industri kecil dan menengah dan mikro yang kini menyerap sekitar 43,2 juta tenaga kerja.

\section{Dampak ekonomi}

Dari berbagai pemberitaan media massa diketahui berbagai keluhan dari produsen tentang berbagai dampak yang ditimbulkan akibat pemberitaan tersebut, sebagaimana diperlihatkan pada tabel 2 . Berdasarkan tabel 2, dapat dikemukakan 
Tabel 2. Dampak Pemberitaan Penggunaan Fomalin Dalam Usaha Perikanan Table 2. Impact of Formalin Usage Announcement in Fisheries Bussiness

\begin{tabular}{|c|c|c|}
\hline $\begin{array}{l}\text { Media Massa/Mass } \\
\text { Me dia }\end{array}$ & Lokasi/Location & Dampak Bagi Produsen/Impact to Producer \\
\hline $\begin{array}{l}\text { Suara Merdeka, } 2 \\
\text { Januari 2006/Suara } \\
\text { Merdeka, January 2, } \\
2006\end{array}$ & $\begin{array}{l}\text { Desa Sidomulyo, kec } \\
\text { Sluke, Rembang, } \\
\text { jawa Tengah }\end{array}$ & $\begin{array}{l}\text { Walaupun pengusaha terasi tersebut tidak } \\
\text { menggunakan formlain namun terkena imbasnya yaitu } \\
\text { menurunnya jumlah pesanan hingga mencapai } 25 \% / \\
\text { Fish paste market/order decreased by } 25 \% \text { eventhough } \\
\text { the producer didn't use the formalin in the product }\end{array}$ \\
\hline $\begin{array}{l}\text { Jawa pos, } 6 \text { Januari } \\
\text { 2006/ Jawa Pos, January } \\
6,2006\end{array}$ & Tegal & $\begin{array}{l}\text { Pengusaha Ikan asin rugi ratusan juta akibat produk } \\
\text { yang dikirim ke Palembang tidak laku terjual.. Harga } \\
\text { ikan asin turun dari Rp. 8000/kg menjadi Rp. 1500/kg. } \\
\text { Terjadi PHK tenaga kerja yang bekerja di perusahaan } \\
\text { pengasinan ikan/Salted fish product marketed in } \\
\text { Palembang was rejected, the producer loss hundreds of } \\
\text { million rupiah. The price droped from Rp. 8000/kg to } \\
\text { Rp. } 1500 / \mathrm{kg} \text {. Employees in salted fish industries were } \\
\text { retired. }\end{array}$ \\
\hline $\begin{array}{l}\text { Suara merdeka, } 19 \\
\text { Januari 2006/ Suara } \\
\text { Merdeka, January 19, } \\
2006\end{array}$ & Rembang & $\begin{array}{l}1600 \text { ton ikan asin tidak laku dijual. Akibatnya } \\
\text { se banyak } 500 \text { orang pekerja sudah dirumahkan akibat } \\
\text { berhentinya usaha ikan asin./ } 1600 \text { tons of salted fish } \\
\text { rejected from the market. } 500 \text { employee in the } \\
\text { industries sent to home. }\end{array}$ \\
\hline $\begin{array}{l}\text { Jawa Pos, } 23 \text { Januari } \\
\text { 2006/ Jawa Pos, January } \\
\text { 23, } 2006\end{array}$ & Rembang & $\begin{array}{l}\text { Harga ikan di tingkat nelayan turun hingga } 50 \% \text { karena } \\
\text { banyak pedagang yang tidak ikut lelang seh ingga ikan } \\
\text { menumpuk di TPI sehingga pendapatan nelayan } \\
\text { menurun./ The fish price at the fisherman level } \\
\text { decreased by } 5 \% \text {, auctioner withdrawn from the FCP. } \\
\text { Fisherman income desreased. }\end{array}$ \\
\hline $\begin{array}{l}\text { Suara Merdeka, } 23 \\
\text { Januari 2006/ Suara } \\
\text { Merdeka, January 23, } \\
2006\end{array}$ & Semarang & $\begin{array}{l}\text { Pedagang ikan di pasar Kobong pendapatannya } \\
\text { menurun sampai 30\%, akibat penurunan transaksi dan } \\
\text { harga ikan yang turun mencapai Rp. } 1000-3000 / \\
\text { kg/Fish seller income at Kobong Market decrease by } \\
30 \% \text {. The fish price dropped by Rp. } 1000-\text { Rp. } 3000 / k g\end{array}$ \\
\hline $\begin{array}{l}\text { Suara Merdeka, } 24 \\
\text { Janurai 2006/ Suara } \\
\text { Merdeka, January 24, } \\
2006\end{array}$ & Demak & $\begin{array}{l}\text { Akibat sepi pembeli, pedagang menurunkan harga ikan } \\
\text { hingga } 40 \% \text {./Fih demand decrease, the selling price at } \\
\text { the market level dropped by } 40 \%\end{array}$ \\
\hline $\begin{array}{l}\text { Kompas, } 8 \text { Februari } \\
2006 / \text { Kompas February } \\
8,2006\end{array}$ & $\begin{array}{l}\text { Kabupaten Seruyan, } \\
\text { Kalimantan } \\
\text { Tengah }\end{array}$ & $\begin{array}{l}\text { Nelayan di kabupaten Seruyan, Kalimantan } \\
\text { Tengah mengalami penurunan pendapaan } \\
\text { akibat menurunnya harga ikan hasil tangkapan/Fishermar } \\
\text { income of Seruyan Distri } \\
\text { ct, Central Kalimantan deceased since the price of fresh } f \\
\text { dropped. }\end{array}$ \\
\hline
\end{tabular}

bahwa terungkapnya penyalahgunaan formalin sebagai pengawet pada produk produk perikanan menimbulkan kerugian bagi para industri dan padagang makanan, serta berpotensi akan mengakibatkan hilangnya lapangan kerja di sektor ini.

Dampak negatif pemberitaan penggunaan formalin lebih dirasakan oleh nelayan dan pengolah ikan khususnya ikan asin dan terasi. Akibat adanya pemberitaan tersebut produk mereka untuk sementara waktu banyak yang tidak terjual dan dihargai sangat murah. Walaupun nelayan yang tidak menggunakan formalin tetap saja ikan hasil tangkapannya sulit dijual, sehingga menyebabkan mereka merugi dan tidak melaut untuk beberapa saat. Begitu pula bagi pengolah ikan asin dan terasi untuk sementara 
waktu terjadi pengurangan penjualan ikan hasil olahannya.

Sisi positif dari pemberitaan tersebut yaitu bertambahnya kesadaran nelayan untuk kembali menggunakan es. Hasil pengamatan dan wawancara di lapangan terdapat perubahan pada tingkat nelayan di Muara Angke, Jakarta, saat ini nelayan telah membawa es untuk mengawetkan ikan hasil tangkapannya di laut. Produsen ikan asin, saat ini tidak lagi menggunakan bahan kimia formalin sebagai pengawet. Sisi positif lain terjadi untuk pembudidaya ikan adalah terjadi peningkatan terhadap ikan hidup hasil budidaya sejak adanya pemberitaan formlain. Hal ini diperoleh dari hasil wawancara dengan instansi terkait yaitu Dinas Perikanan Propinsi Jawa Barat dan beberapa pedagang di Muara Angke, Jakarta dan Bandar Lampung serta Semarang.

Persepsi dari produsen, misalnya pengolah merasa dirugikan dengan adanya pemberitaan tersebut. Sebagai contoh dikemukakan oleh respoden nelayan di Kabupaten Karawang yang menyatakan bahwa sejak isu formalin merebak, ikan hasil tangkapannya mengalami penurunan harga, padahal mereka tidak menggunakan formalin (operasi penangkapannya hanya satu hari). Hal yang sama juga dikemukakan oleh para nelayan lokal di Bandar Lampung. Akibat pemberitaan tersebut harga ikan di tempat pelelangan turun drastis, padahal ikan yang didaratkan di TPI tersebut yang mengandung formalin berasal dari nelayan andon. Namun demikian akibat penemuan tersebut seluruh ikan yang didaratkan dituduh menggunakan formalin.

Untuk ikan segar kerugian yang dirasakan nelayan adalah terjadinya penurunan harga yang jauh di bawah standar. Sebagai contoh untuk ikan bawal putih sebelum ada isu formalin bernilai Rp 85.000,$/ \mathrm{kg}$, tetapi setelah ada isu formalin menjadi hanya Rp.45.000,-/kg. Nilai selisihnya merupakan kerugian nelayan yang harus dipikul sebagai akibat adanya isu penggunaan formalin pada ikan hasil tangkapa di wilayah tersebut.

\section{Dampak sosial}

Dampak sosial dari pemberitaan penggunaan formalin pada produk perikanan pada produsen dan konsumen dicirikan dengan perubahan prilaku dalam memproduksi dan konsumsi produk ikan dan olahannya. Hasil wawancara terhadap responden di beberapa wilayah di Bandar Lampung, Karawang, dan Semarang, diketahui bahwa konsumen merasa ketakutan dan khawatir dengan mengkonsumsi ikan. Ketakutan tersebut tidak hanya terbatas dalam mengkonsumsi ikan segar tetapi juga pada ikan hasil olahan. Dengan demikian, kalaupun mereka ingin mengkonsumsi ikan mereka lebih memilih mengkonsumsi ikan air tawar segar atau hidup dibandingkan dengan ikan laut. Hal ini didukung oleh pernyataan dari Dinas Perikanan Propinsi Jawa Barat, yang mengemukakan bahwa walaupun tidak ada jumlah yang tepat, namun selama pemberitaan formalin beredar ada indikasi terjadinya peningkatan permintaan konsmen terhadap beberapa jenis ikan air tawar. Dengan demikian, bertambahnya informasi konsumen dalam kaitannya dengan dampak penyalahgunaan formalin menambah sikap kehati-hatian mereka dalam mengkonsumsi ikan dan olahannya.

Perubahan perilaku konsumen terlihat pula dari hasil wawancara terhadap pembeli ikan di Bandar Lampung (Pasar Kalianda dan Pasar Hanura), Karawang (Pasar Johar), Semarang (Pasar Kobong dan Pasar Rejomulyo), dalam memilih jenis ikan yang akan dibeli maka konsumen berhati-hati sekali. Di samping memilih ikan yang masih segar juga mereka harus mengetahui asal ikan tersebut, karena mereka mengganggap ikan yang mereka tidak ketahui lokasi penangkapannya mereka meragukan. Dengan demikan, setelah ada pemberitaan 
formalin responden lebih memilih telur atau tempe sebagai alternatif lain pengganti ikan.

Bagi produsen, akibat pemberitaan penyalahgunaan formalin telah terjadi beberapa perubahan pola produksi baik pada tingkat nelayan maupun tingkat pengolah perikanan. Isu formalin telah berakibat secara langsung terhadap usaha produsen dan pedagang ikan, maka sedikit demi sedikit telah banyak merubah cara yang dilakukan dalam pengolahan dan penanganan ikan. Nelayan tidak lagi memilih formalin untuk mengawetkan hasil tangkapan. Pengolah juga sudah tidak menggunakan formlain, hal ini dapat dibuktikan dari data Jawa Pos tanggal 16 Januari 2006 tercatat bahwa di Semarang diperkirakan hanya tinggal ikan asin berformalin dari seluruh ikan asin yang beredar di Jawa Tengah saat itu. Produk tersebut merupakan sisa produk lama sebelum isu formalin merebak.

Data lain yaitu produsen ikan olahan dan terasi cenderung untuk tidak menggunakan formalin sebagai bahan pengawet. Hal ini dapat diketahui dari informasi Suara Merdeka tanggal 1 Nopember 2005, di Pekalongan, berdasarkan hasil pengecekan Laboratorium Perikanan maka tidak ditemukan bahan formalin dalam produk ikan asin dan pemindangan. Berbarengan dengan itu, pemerintah Kota melarang para pengusaha ikan asin dan pemindangan ikan di wilayah kota itu menggunakan formalin untuk mengawetkan hasil produksi mereka.

\section{Penanggulangan Dampak Pemberitaan Formalin}

Berbagai aksi nyata telah dilakukan dalam upaya penanggulangan dampak pemberitaan formalin yaitu mencoba meyakinkan kembali konsumen bahwa makan ikan itu aman. Departemen Kelautan dan Perikanan sebagai institusi yang terkait langsung telah mengeluarkan 6 langkah seperti terlihat dalam "Siaran Pers Departemen Kelautan dan Perikanan No.
78/PIPM/XI1/2005" tentang Sikap DKP terhadap Penggunaan Formalin pada Produk Perikanan, diantaranya:

a. Pertama, Pemerintah secara bertahap akan menerapkan sistem sertifikasi bagi unit pengolahan ikan skala kecil, sebagaimana yang telah diterapkan bagi unit pengolahan ikan skala besar. Sertifikasi tersebut diberlakukan dalam rangka menjamin bahwa praktik penanganan dan pengolahan ikan yang dilakukan telah memenuhi persyaratan yang ditentukan, yaitu sesuai dengan konsepsi HACCP (Hazard Analysis Critical Control Point);

b. Kedua, Pemerintah akan menerapkan labelisasi terhadap unit pengolahan dan produknya, dan seafood outlet (pasar ikan, restoran, warung, swalayan dan lain-lain) dalam rangka menjamin bahwa produk tersebut bebas dari bahan kimia yang dilarang digunakan untuk makanan atau non food grade Pernyataan dalam label dimaksud adalah Bebas Formalin (Formalyn Free) atau sejenisnya yang substansinya sama. Labelisasi ini akan bersinergi dengan Pasar Ikan Higienis yang sudah dan sedang dibangun serta lembaga sertifikasi lainnya. Program ini akan segera dilaksanakan sebagai percontohan di wilayah Jakarta Utara, bekerjasama dengan Dinas Peternakan, Perikanan dan Kelautan Provinsi DKI Jakarta;

c. Ketiga, dalam kaitannya dengan program labelisasi, maka telah dikembangkan metoda uji formalin (kualitatif) dengan cara cepat (rapid test). Hal ini sekaligus dimaksudkan untuk membantu masyarakat agar dapat mengetahui dengan cepat, suatu produk perikanan mengandung formalin atau tidak;

d. Keempat, Pemerintah akan mengintensifkan penerapan cool chain system (sistem rantai dingin) dalam seluruh rantai produksi, distribusi dan pemasaran 
hasil perikanan. Penerapan sistem ini telah terbukti mampu mempertahankan kesegaran dan mutu ikan, sehingga penggunaan bahan kimia tambahan tidak lagi diperlukan. Dalam implementasinya, pemerintah akan memperbanyak pabrik es di sentra-sentra produksi perikanan, menyediakan cool box untuk penyimpanan ikan serta sarana-sarana lain yang diperlukan;

e. Kelima, khusus untuk produk-produk olahan, DKP akan mengintroduksi penggunaan bahan pengawet alternatif (food grade) terutama bahan pengawet alami, sebagai pengganti bahan pengawet buatan. Dalam kaitan itu, riset dan uji coba untuk menemukan jenis bahan dan konsentrasi yang tepat akan lebih digalakkan lagi;

f. Keenam, simultan dengan langkahlangkah di atas, kami juga akan mengintensifkan kegiatan sosialisasi tentang larangan penggunaan bahan kimia berbahaya dalam penanganan dan pengolahan ikan, melalui penyebarluasan informasi dengan menggunakan leaflet, brosur, poster dan lain-lain serta pembinaan dan bimbingan secara langsung bagi para pengolah hasil perikanan. Di samping itu, penegakan hukum (law enforcement) akan dilaksanakan secara konsisten bagi masyarakat yang melanggar peraturan perundang-undangan yang berlaku.

Dalam hal membatasi penggunaan formalin, pemerintah harus mengurangi peredaran dan pengawasan yang ketat terhadap peredaran formalin. Hal yang telah dilakukan yaitu dengan dibentuknya Tim pengawasan yang diketuai Menteri Kesehatan ini beranggotakan BPOM, Menteri Pertanian, Menteri Perdagangan yang akan mengawasi impor dan distribusi bahan tersebut. Produk kimia tersebut hendaknya tidak didistribusikan pada pengusaha kecil yang bergerak di bidang makanan dan minuman. Kemudian, tim penyelamatan industri terdiri dari Menteri Perdagangan, Menteri Koperasi dan UKM, dan Menteri Tenaga Kerja dan Transmigrasi. Tim ini akan menata kembali tata niaga dan distribusi formalin.

Departemen Perdagangan (Depdag) juga akan menyempurnakan SK Menperindag Nomor 254/MPP/Kep/7/2000 tentang Tata Niaga Impor dan Peredaran Bahan Berbahaya Tertentu. Impor formaldehyde menjadi item yang ditataniagakan Depdag sebagai bahan berbahaya. Sebelumnya SK ini hanya mengatur 351 item yang tergolong bahan berbahaya. Direktur Jenderal Perdagangan Dalam Negeri Depdag, mengemukakan bahwa dengan dimasukkannya paraformaldehyde tersebut berarti akan ada 352 item yang ditataniagakan sebagai bahan berbahaya. Selain itu, Depdag juga akan mengatur tataniaga penjualan formalin dari produsen ke distributor, sehingga tidak akan bebas di pasaran. Pembeli formalin, yang terdiri dari 37 persen formaldehyde dalam air, nantinya harus menunjukan identitas diri dan tujuan pembelian saat hendak membeli cairan kimia ini. Depdag pun akan mengatur tata niaga formalin produksi dalam negeri. Sanksi atas pelanggaran penggunaan formalin pada bahan makanan pun akan sama, yaitu merujuk pada Undang-Undang Perlindungan Konsumen No. 8 Tahun 2000. Depdag juga akan mengupayakan cara pengaturan distribusi formalin secara terbatas, sehingga penggunaannya dapat terkontrol. Selama ini realisasi impor formalin di Indonesia menunjukkan angka yang sangat kecil dibandingkan dengan izin impornya. Dari 24 ribu ton izin impor formalin untuk tahun 2005 bagi dua perusahaan produsen importir bahan berbahaya, realisasinya hanya sebesar 7,4 ton, sedangkan dari importir terdaftar realisasinya hanya 100 liter dari 6.100 ton formalin yang diizinkan. Dengan demikian, beredarnya bahan makanan yang mengandung formalin, dapat dipastikan menggunakan pasokan formalin produksi 
dalam negeri. Dari 20 perusahaan dengan kapasitas produksi 806.400 ton per tahun, realisasi produksinya adalah 40 persen atau 322.560 ton. Dari 322.560 ton formalin yang dijual melalui distributor berkisar 3 persen dari angka itu, yakni sekitar 10.000 ton per tahun. Rata-rata per bulannya sekitar 1.000 ton formalin yang dijual lewat distributor.

Tim penyuluhan diketuai Menkominfo akan memberikan penyuluhan kepada produsen makanan dan minuman tentang alternatif pengawet dan pewarna makanan yang aman bagi kesehatan. Selain itu mereka diberi pengetahuan tentang tata cara registrasi produk makanan. Untuk memperoleh nomor registrasi produsen harus menyampaikan sampel bahan baku, proses yang dipakai, dan kemasan yang dipergunakan untuk diuji. Bila bahan tersebut aman maka mereka akan mendapat nomor registrasi.

Dari sisi riset terkait dengan penggunaan bahan alternatif pengganti formalin harus terus dilakukan. Sejalan dengan hal tersebut Komisi B DPRD DKI Jakarta, mendesak Dinas Peternakan, Perikanan, Kelautan (Dinas P2K) DKI segera membuat alternatif bahan pengawet ikan segar dan ikan asin. Kemudian, Komisi B DPRD DKI Jakarta juga mengusulkan penggunaan teknologi mesin pengawet ikan segar (cold storage) di sejumlah tempat pelelangan ikan (TPI) di Jakarta. Sisitem pengawetan juga berlaku untuk produksi ikan asin, termasuk kemasannya. Menurut Sekretaris Komisi B DPRD DKI, penyediaan alternatif teknologi pengawet ikan segar dan ikan asin itu sudah sangat mendesak. Jika tidak, nelayan akan terus menggunakan formalin untuk pengawetan ikan tangkapannya. Dampaknya masyarakat terkena banyak penyakit sebagai imbas dari penggunaan formalin

Kepala Dinas P2K DKI, Edi Setiarto mengatakan bahwa salah satu solusi menghilangkan penggunaan formalin pada tingkat nelayan adalah dengan cara mengoptimalkan kapal fish carrier vessel (kapal pengangkut ikan). Caranya, fish carrier vessel mendatangi kapal-kapal nelayan lalu mengangkut ikannya untuk kemudian dibawa ke pelelangan ikan di TPI. Dengan cara seperti itu, ikan hasil tangkapan bisa diambil langsung dan dilelang, sehingga penggunaan formalin oleh nelayan akan berkurang atau dihilangkan sama sekali. Hanya saja, diakuinya, pihaknya masih membahas pola pengangkutan ikan dengan fish carrier tersebut. Termasuk tenaga yang mengoperasikan kapal tersebut.

Penanganan dan pengawetan produk perikanan terutama pada tingkat masyarakat nelayan juga dapat dilakukan dengan menyediakan produk es dengan harga yang terjangkau. Misalnya, di DKI Jakarta, Gubernur Sutiyoso mengemukakan bahwa harga es dari pabrik yang diresmikan di sekitar Muara Angke - Jakarta Utara adalah Rp.6.000 per balok sehingga diharapkan terjangkau oleh masyarakat nelayan (Kompas, 19 Januari 2006). Sebelumnya, harga es bisa mencapaai Rp. 14.000 per balok karena diproduksi di luar kawasan Pelabuhan Perikanan Muara Angke. Dengan harga balok es yang dapat ditekan menjadi semakin murah, diharapkan nelayan mau meninggalkan formalin meskipun pengawet tersebut lebih ekonomis.

Seorang nelayan di Muara Angke, Rakhim mengakui bahwa penggunaan formalin sudah ditinggalkan bertahun-tahun lalu karena sudah tidak lagi menangkap ikan hingga berhari-hari. Saat ini ia turun ke laut untuk menangkap ikan dalam sehari, kemudian bersandar lagi untuk menjual hasil tangkapannya. Dalam sehari saya membeli 200 balok es. Harga balok es yang di beli di Muara Angke selama ini Rp. 12.000 per balok. Kemarin Rakhim membeli es dari PT AGB Tuna dengan harga Rp. 8.500 per baolk dan sudah dihancurkan. PT AGB saat ini meminta bantuan kepada Sutiyoso untuk mengembangkan pabrik es beserta sarana pengawetan dan pengolahahn ikan . PT AGB menyatakan bersedia membangun kembali pabrik serupa di atas lahan 10 hektar dengan dilengkapi pula dengan sarana pengolahan air 
menjadi air bersih.

Dilain pihak, lewat penelitiannya, Hangesti membuktikan bahwa pucung dapat dimanfaatkan sebagai pengawet ikan segar. Dalam paparan risetnya itu, menjelaskan bahwa panggunaan daging biji kluwak dapat mengawetkan ikan telah memberikan hasil. Kombinasi $2 \%$ kluwak dengan $2 \%$ garam telah mampu mengawetkan ikan kembung segar (Rastrelliger Brachysoma) selama 6 hari, tanpa mengubah mutu (Anonimous, 2006). Hal ini merupakan terobosan untuk mengatasi keadaan sulit diperolehnya dan mahalnya harga es batu untuk mempertahankan mutu ikan. Juga untuk menghindari penggunaan larutan formalin yang berbahaya bagi kesehatan manusia. Pengawetan ikan segar dengan menggunakan kluwak dan garam sudah dilakukan para nelayan di Kecamatan Labuan, Propinsi Banten secara turunmenurun.

Proses pengawetan dimulai dengan mengupas biji pucung. Kemudian dilakukan pencacahan daging biji picung, dan dilanjutkan pencampuran cacahan biji pucung itu dengan garam. Campuran itulah yang dilumurkan pada ikan kembung segar. Ikan kemudian dikemas dalam ember plastik tertutup, yang setiap hari dibuka selama lima menit, dan dilakukan penyimpanan (dalam suhu kamar). Ujiannya selanjutnya dilakukan selama tiga hari sekali dalam dua minggu. Ternyata ikan kembung dapat awet tanpa berubah mutunya. Harga 1 kg kluwak di pasar rata-rata Rp. 3.000. Sedangkan cacahan daging buah itu seharga Rp 10 ribu. Dengan cacahan daging buah pucung yang senilai Rp 10 ribu itu bisa mengawetkan ikan segar sebanyak 50 kg. Ini jauh lebih murah dibandingkan dengan es balok yang harganya Rp 25.000 per balok. Biji buah pucung ini mengandung asam sianida dan tanin.

Selanjutnya, pengasapan adalah salah satu cara pengawetan ikan yang dikenal manusia. Namun, pada ikan asap yang proses pembuatannya konvensional, hanya diasapi dengan bara api, masih mengandung tar dan benzopyrene. Kedunya adalah penyebab kanker, sedangkan ikan yang diawetkan dengan asap cair tidak berbahaya bagi kesehatan, juga masih layak dikonsumsi hingga sebulan, sama seperti ikan yang diasapkan dengan cara konvensional (Prasetya, 2006). Meskipun tidak sehebat formalin yang bisa mengawetkan makanan hingga berhari-hari bahkan berbulan-bulan, atau bertahun-tahun, asap cair yang terpenting adalah aman bagi kesehatan.

Asap cair juga dapat memperpanjang umur simpan makanan, seperti tahu, daging ikan segar, mie, atau bakso. Hasil samping berupa arang juga bisa dipakai sebagai bahan bakar. Arang lebih menguntungkan dibanding kayu bakar karena memberikan kalor pembakaran lebih tinggi dan asap sedikit. Selain itu, tungku pembakar stainless yang dirakitnya tahun 1995, hanya menelan biaya sekitar Rp 5 juta. Di pasaran, asap cair memang sudah beredar dengan harga per liter sekitar Rp 6.000, namun, itu adalah asap cair yang bukan untuk mengawetkan makanan, melainkan pembeku dan pengawet karet alam.

Beberapa alternatif pemecahan masalah yang dikemukakan diatas merupakan pemecahan yang bersifat teknis yaitu penjualan formalin yang diperketat, pencarian bahan pengawet alternatif hingga sertifikasi terhadap produk, Terkait dengan pemecahan masalah tersebut, Suparto (2006) mengemukakan bahwa solusi serius dari formalinisme bukanlah melulu soal teknis, tetapi akar persoalan adalah moralitas. Kalau soal moral tetap sepereti sekarang ini, segala aturan teknis masih bisa "diakali" untuk dilanggar. Pelaku tidak memiliki kontrol nurani. Pejabat, aparat hukum, maupun elemen kekuasaan lain merupakan unsur yang bisa ditaklukkan. Lagi-lagi cara illegal menjadi andalan. Agar formalinisme ditinggalkan penganutnya, maka tak ada pilihan lain kecuali membangun moralitas melalui peran fondasi agama. Memang ada perdebatan tentang hubungan moralitas dan agama. Rachels (2003) jelas-jelas membedakan moralitas dan 
agama. Moralitas itu menyangkut soal akar dan kesadaran, bukan iman keagamaan. Dalam kasus tertentu, kesadaran keagamaan tidak menjamin pemecahan definitif terhadap masalah-masalah moral yang dihadapi manusia.

Filsuf moral lainnya, Hazlitt (2003), mengemukakan agama dan moralitas seperti dua arus yang sering kali berjalan pararel, bercampur, terpisah, tampak independen dan acap kali sering juga bergantung. Dalam kontek saling bergantung ini yang sering terjadi adalah "saling menopang" Kepercayaan religius menopang moralitas. Hal ini semta-mata berangkat dari kepercayaan bahwa Tuhan melihat setiap tindakan seseorang. Jadi orang beriman takut tidak baik. Inilah kekuatan besar dalam perilaku etis. Sebagian besar pemuka di negeri ini cenderung menganut konsep Hazlitt. Orang religius semestinya lebih mempertimbangkan moralitas. Atas dasar inilah pemuka agama mempunyai peran yang memperbaiki moral bangsa. Mereka membangun kekuatan moral bukan sekedar lewat caramah agama, tetapi juga teladan.

Kemudian, dari sisi konsumen juga dapat diantisipasi penyalahgunaan formalin dengan tersedianya tes kit formalin yang berwujud kertas indikator yang akan berubah warna ketika dicelupkan ke dalam air bilasan makanan yang mengandung formalin. Bila, bagian kertas berubah ungu, maka makanan yang di tes dapat dipastikan diproduksi menggunakan formalin. Hal ini telah diuji di laboratorium dengan hasil bahwa semakin besar kandungan formalin dalam produk makanan, perubahan warna setelah dicelupkan ke air bilasan akan semakin jelas (Kompas, 25 Januari 2006). Pengendalian tataniaga formalin (khusus untuk rumah sakit dan industri kayu lapis). Tim tersebut berasal dari Departemen-Departemen Kesehatan, Perindustrian, Perdagangan, Komunikasi dan Informasi, Tenaga Kerja dan Transmigrasi, Kementerian Koperasi dan UKM, dan Badan Pengawasan Obat dan Makanan (BPOM). Tim kecil pertama yang menangani masalah penanggulangan terhadap pemakaian bahan pengawet berbahaya pada makanan dan minuman dilakukan Depkes, Depperdag dan BPOM. Tim kedua akan melakukan penyelamatan terhadap industri yang dilakukan Depperin, Depnakertrans, serta Depkop dan UKM. Tim ketiga melakukan penyuluhan dilakukan Depkominfo, Depkes, Depperdag dan BPOM.

Keseluruhan tim tersebut, akan membuat konsep mengenai empat masalah, sehingga bisa menjaga kesehatan masyarakat dan juga menanggulangi masalah pengangguran, yaitu pertama, tindakan penyuluhan secara positif kepada msyarakat tentang bahan-bahan pengawet berbahaya agar produsen, dan importir mengetahui. Kedua, pengawasan terhadap produksi, distribusi, dan impor akan dilakukan secara ketat. Pemerintah akan membentuk satu lembaga pengawasan produk makanan dan minuman untuk melakukan penataan lebih baik dengan melibatkan sejumlah departemen dan instansi terkait. Ketiga, masalah hukum, yakni membuat peraturan untuk melengkapi UU yang sudah ada dengan melarang penggunaan bahan pengawet berbahaya. Juga akan mengambil tindakan hukum yang tegas terhadap pemakai dan penjual yang menggunakan produk pengawet berbahaya. Keempat, melakukan penyelamatan terhadap industri-industri kecil dan menengah yang terkena dampak kasus formalin. Untuk mencegah penggunaan formalin pada ikan, pihaknya menawarkan bahan alternatif yakni minatrit. Zat ini dinilai aman sebagai pengawet karena tidak mengandung residu dan tidak bereaksi dengan senyawa lain yang memicu kanker. Penggunaan pengawet ini telah mendapat rekomendasi dari badan kesehatan dunia di antaranya dari Organisasi Kesehatan Dunia (WHO) dan Badan Pangan Dunia (FAO). Rencananya, pengawet ini akan diedarkan ke sentra industri pengolahan perikanan. 


\section{KESIMPULAN}

Pemberitaan penyalahgunaan formalin untuk produk perikanan telah memberikan dampak antara lain menurunkan permintaan ikan, baik segar maupun olahan, menurunkan omzet penjualan dan menurunkan harga ikan. Akibatnya, produsen, baik nelayan, pengolah bahkan pedagang telah mengalami kerugian dan penurunan pendapatan. Sementara itu dampak lainnya bertambahnya pengangguran akibat PHK dari industri pengolahan ikan. Bertambahnya pengetahuan baik produsen dan konsumen tentang bahaya penggunaan dan mengkonsumsi formalin dalam produk makanan termasuk ikan. Telah terjadi perubahan pola produksi oleh nelayan dan pengolah dari yeng menggunakan formalin untuk mengawetkan ikan kembali menggunakan es atau garam. Perubahan pola konsumi masyarakat dari konsumsi ikan ke telur/tempe atau ikan hidup hasil budidaya juga terjadi pada beberapa wilayah terutama Jawa Barat.

Agar pemberitaan tersebut tidak terulang lagi dan mengembalikan kepercayaan masyarakat untuk kembali mengkonsumsi ikan dan produk olahannya beberapa hal yang perlu dilakukan, antara lain pemerintah harus lebih memperketat peredaran formalin dan mempercepat sertifikasi produk makanan yang bebas formalin. Pemerintah memberikan penyuluhan yang berkesinambungan baik terhadap produsen dan konsumen tentang bahayanya mengkonsumsi makanan yang berformalin. Hal yang penting juga adalah penegakan sanksi pidana harus dilaksanakan dengan tegas seperti yang tertera dalam aturan yaitu merujuk pada Undang-Undang Perlindungan Konsumen No.8 Tahun 2000. Disamping itu, mengupayakan alternatif bahan alami pengganti formalin seperti buah picung atau pengasapan yang dapat dimanfaatkan sebagai pengawet ikan segar.

\section{DAFTAR PUSTAKA}

Balai Besar Riset Sosial Ekonomi. 2005. Analisis Kebijakan Dampak Penggunaan Formalin Terhadap Sektor Kelautan dan Perikanan. Laporan Teknis. Jakarta: BBRSE

Dunn, W. N., 2000. Pengantar Analisis Kebijakan Publik. Edisi Kedua. Yogyakarta: Gadjah Mada University Press. $687 \mathrm{p}$.

Fardiaz, Dedi. Konsumen Bisa Uji Formalin Sendiri. Kompas 25 Januari 2006.

Hazlitt, H., 2003. Dasar-Dasar Moralitas.Yogyakarta: Pustaka Pelajar.

Nazir, M., 1988. Metode Penelitian. Jakarta: Ghalia Indonesia.

Prasetya, L. A. Melawan Formalin dengan Asap Cair. Kompas. 17 Januari 2006.

Rachels, J., 2004. Filsafat Moral. Yogyakarta: Kanisius.

Simatupang, P. 2003. Analisis Kebijakan:

Konsep Dasar dan Prosedur

Pelaksanaan. Analisis Kebijakan

Pertanian. Pusat Penelitian dan

Pengembangan Sosial Ekonomi

Pertanian. Badan Penelitian dan

Pengembangan Pertanian.

Departemen Pertanian. I (1): 14-35.

Singarimbun, M. dan S. Effendi. 1989. Metode

Penelitian Survei. Jakarta: LP3ES.

Suparto, T. Formalin(isme). Kompas. 28 Januari 2006.

Sutiyoso. Nelayan Angke Diminta Hindari Formalin: Gubernur Sutiyoso Resmikan Pabrik Es Batu. Kompas 19 Januari 2006.

Widagdo. Tidak Benar Pengusaha Ikan Asin Pakai Formalin. Suara Merdeka 1 November 2005. 